\title{
Increased Soil Water Storage and Herbage Production from Snow Catch in North
} Dakota

\author{
R.E. RIES AND J.F. POWER
}

\begin{abstract}
This study documents the effect of three grass stubble heights $(15,30$, and $60 \mathrm{~cm})$ on overwinter storage of soil water and the subsequent effect on forage production the following growing season. Soil water was increased over the winter by $0.24 \mathrm{~cm}$ for each centimeter of grass stubble left between 15 and $60 \mathrm{~cm}$ in height. Each centimeter increase in soil water stored over the winter increased forage production by 115 and $62 \mathrm{~kg} / \mathrm{ha}$ for introduced and native species, respectively. Results indicate the importance of stubble height in increasing forage production from grasslands of the Northern Great Plains by trapping snow and storing soil water for use by the plant community the following growing season.
\end{abstract}

Snow catch and the resulting meltwater can be an important source of soil water for dryland agriculture. Matthews (1940) discussed the importance of using snow meltwater in Canadian prairie agriculture in Saskatchewan and described some of the methods used for trapping snow. Willis and Haas (1969) discussed the importance of snow as a source of water in the Northern Plains.

Various techniques have been used over the years to increase snow catch and subsequent storage of meltwater for use in agricultural production. Haas and Willis $(1968,1971)$ reported that conservation bench terraces and level bench terraces increased the snow catch and reduced snow melt runoff when compared with nonterraced areas. The additional soil water stored on the benched areas significantly increased crop and forage production. Rauzi (1973) reported similar findings from the use of level bench terraces in northeastern Wyoming.

Perennial grass barriers of tall wheatgrass (Agropyron elongatum Host.) provided effective snow catch and erosion control in northeastern Montana (Black and Siddoway 1971). Greb and Black (1971) evaluated vegetation barriers and artificial fences for managing snow in the Central and Northern Plains. Both techniques enhanced snow catch, resulting in more soil water available for use by desired vegetation. Pitting and interseeded crested wheatgrass (Agropyron spp.) increased trapped snow resulting in increased soil water storage, forage and annual carrying capacity of native shortgrass rangeland in southeastern Wyoming (Rauzi 1968). Wight et al. (1975), discussing snow management in relation to eastern Montana rangeland, pointed out that snow management on the semiarid rangelands of the Northern Great Plains could provide a hedge against drought. They believe new ideas and research can lead to more effective use of snow as a resource for rangeland. Nicholaichuk and Norum (1975) addressed snow management on the Canadian prairies. They described snow distribu-

\footnotetext{
Authors are range scientist and soil scientist, Northern Great Plains Research Center, U.S. Dep. Agr., Agricultural Research Service, P.O. Box 459, Mandan, North Dak ota 58554. J.F. Power is currently soil scientist, U.S. Dep. Agr., Agr. Res. Serv., Univ. of Nebraska, Keim Hall, East Campus, Lincoln 68583.

This report is a contribution from U.S. Department of Agriculture, Agricultural Research Service.

Manuscript received January 25, 1980.
}

tion, the history of snow management, the influence of shelterbelts on snow accumulation, and the effect on snow trapping by swathing grain at alternate stubble heights. Data collected for 1973-75 showed that wheat stubble (Triticum aestivum L.) swathed at alternate stubble heights of 12 to 5 inches $(30$ to $13 \mathrm{~cm}$ ) consistently trapped more snow and retained more potentially available water than uniformly swathed stubble.

The objectives of this study were: (1) to document any change in soil water storage from trapped snow as affected by three grass stubble heights, (2) to document the response of forage production the following growing season to the increased stored soil water.

\section{Study Area and Methods}

This study was conducted at the Northern Great Plains Research Center, Mandan, North Dakota, during the winter of 1976-77 and the summer of 1977. The soil was a Parshall fine sandy loam (a member of the fine-loamy, mixed family of Pachic Haploborolls). This soil holds about $4.72 \mathrm{~cm}$ of water at field capacity and $1.83 \mathrm{~cm}$ of water at the wilting point per $30 \mathrm{~cm}$ of soil depth.

Data of precipitation, snowfall, temperature and windspeed during the study period (August, 1976-August, 1977) are given in Table 1 . Weather data were collected approximately $0.4 \mathrm{~km}$ from the study area using U.S. Weather Bureau procedures. Precipitation during the period $(26 \mathrm{~cm})$ was substantially below average (44 $\mathrm{cm})$. Snowfall during the winter of $1976-77$ was $79 \mathrm{~cm}, 7 \mathrm{~cm}$ less than average. Average wind speed during the study period was 5

Table 1. Weather data during study period (Aug. 1976-Aug. 1977) and long-term average (1915-1977) from the weather station at Northern Great Plains Research Center, Mandan, N.D.

\begin{tabular}{|c|c|c|c|c|c|c|c|c|}
\hline \multirow[b]{2}{*}{ Month } & \multicolumn{2}{|c|}{$\begin{array}{l}\text { Precipitation } \\
\text { (cm) }\end{array}$} & \multicolumn{2}{|c|}{$\begin{array}{c}\text { Snowfall } \\
(\mathrm{cm})\end{array}$} & \multicolumn{2}{|c|}{$\begin{array}{c}\text { Average } \\
\text { windspeed } \\
(\mathrm{km} / \mathrm{hr} .) \\
\end{array}$} & \multicolumn{2}{|c|}{$\begin{array}{c}\text { Average } \\
\text { temperature } \\
\left({ }^{\circ} \mathrm{C}\right) \\
\end{array}$} \\
\hline & Actual & Avg. ${ }^{1}$ & Actual & Avg. & Actual & Avg. & Actual & Avg. \\
\hline Aug. '76 & 1.24 & 4.14 & - & - & 5.0 & 6.6 & 22 & 20 \\
\hline Sept. 76 & 1.22 & 3.76 & - & 0.4 & 4.2 & 7.1 & 14 & 14 \\
\hline Oct. 76 & 0.20 & 2.26 & 7.6 & 3.0 & 5.1 & 7.4 & 4 & 7 \\
\hline Nov. '76 & 0.43 & 1.30 & 10.2 & 10.7 & 4.7 & 7.7 & -4 & -2 \\
\hline Dec. 76 & 0.94 & 0.99 & 22.9 & 15.0 & 6.0 & 7.2 & -10 & -9 \\
\hline Jan. 77 & 1.35 & 0.96 & 25.4 & 15.0 & 5.3 & 7.7 & -17 & -13 \\
\hline Feb. 77 & 0.64 & 0.96 & 10.2 & 14.0 & 5.3 & 8.0 & -5 & -10 \\
\hline Mar. 77 & 1.14 & 1.75 & 2.5 & 17.0 & 7.7 & 9.2 & 2 & -3 \\
\hline Apr. 77 & 0.28 & 4.04 & - & 9.1 & 5.5 & 10.3 & 10 & 6 \\
\hline May 77 & 3.66 & 5.43 & - & 1.3 & 5.8 & 9.5 & 18 & 13 \\
\hline June 77 & 5.74 & 8.74 & - & $\mathrm{T}$ & 5.1 & 7.7 & 19 & 18 \\
\hline July 77 & 4.22 & 5.84 & - & - & 6.1 & 6.4 & 22 & 22 \\
\hline Aug. ' 77 & 4.67 & 4.14 & - & - & 5.5 & 6.6 & 17 & 20 \\
\hline Total & 25.73 & $\overline{44.31}$ & $\overline{78.8}$ & $\overline{85.5}$ & & & & \\
\hline
\end{tabular}

'Long-term average 
$\mathrm{km} / \mathrm{hr}$, slightly less than long-term average. The air temperature averaged $7^{\circ} \mathrm{C}$ with $6^{\circ} \mathrm{C}$ the long-term average.

A mixture of introduced forage species and native forage species, both established in 1975 , were used for this study. This experimental area was plowed to a depth of $75 \mathrm{~cm}$ before seeding in the spring of 1975 . The introduced mixture was seeded on level $6 \times 6-\mathrm{m}$ plots at a rate of $18.5 \mathrm{~kg}$ / ha pure live seed composed of $27 \%$ smooth bromegrass (Bromus inermis Leyss.), 37\% Russian wildrye (Elymus junceus Fisch.), 27\% pubescent wheatgrass (Agropyron trichophorum (Link) Richt.), and $9 \%$ alfalfa (Medicago sativa L.). The native mixture was seeded on level $6 \times 6-\mathrm{m}$ plots at a rate of $18.0 \mathrm{~kg} /$ ha pure live seed composed of $20 \%$ slender wheatgrass (Agropyron trachycaulum Link Malte), 20\% western wheatgrass (Agropyron smithii Rydb.), 30\% sideoats grama (Bouteloua curtipendula Michx. Torr.), and $30 \%$ blue grama (Bouteloua gracilis (H.B.K.) Lag. ex Steud.). The established stand of introduced forage species was better than the stand of native forage species. Plot areas were fertilized with $100 \mathrm{~kg} \mathrm{~N} / \mathrm{ha}$ and $45 \mathrm{~kg} \mathrm{P} /$ ha in the spring of 1975 . In the spring of 1976 and 1977,55 and $80 \mathrm{~kg} \mathrm{~N} / \mathrm{ha}$, respectively, were applied.

Three stubble height treatments were randomly assigned at harvest in 1976 (Fig. 1). One area was clipped to a grass stubble height of $30 \mathrm{~cm}$, a second area was clipped to $15 \mathrm{~cm}$ height, and a third area was unclipped $(60 \mathrm{~cm}$ height). Clipped plant material was removed. Since the prevailing winter winds are from the northwest, a 10-m buffer strip was left on the west and a 14-m buffer strip on the north of each area. Buffer strips were composed of the same introduced and native forage species and were in the same stubble height as the associated plot areas. Of the plots available outside the buffer zones, five for each species mixture were randomly selected in each of the three stubble height areas.

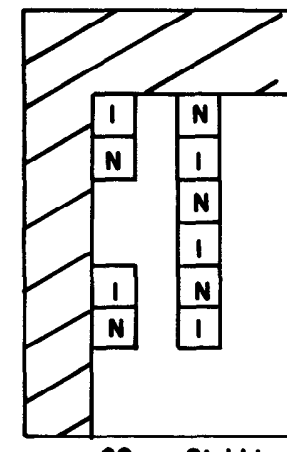

$60 \mathrm{~cm}$ Stubble N-Notive Mixture

Buffer Zone-Introduced a native forage species.
- Introduced Mixture

\section{Fig. 1. Diagram of experimental area.}

Each plot contained a neutron access tube in the center, and soil water content was determined in $30-\mathrm{cm}$ increments to a depth of 1.8 $\mathrm{m}$ in mid-October 1976. Soil water content was measured again in mid-April 1977. The difference between the fall and spring was designated as amount of soil water stored over the winter of 1976-77 under the three stubble height treatments.

In late April 1977, all plots were clipped to a 5-cm height and all clipped material was removed to enhance subsequent herbage production measurements.

Production from the two mixtures was measured at near peak biomass accumulation during the 1977 growing season. Vegetation was clipped by species on ten $30 \times 30-\mathrm{cm}$ plots within each $6 \times 6-\mathrm{m}$ plot. The clipped plant material was oven dried $\left(70^{\circ} \mathrm{C}\right.$ for $24 \mathrm{hr}$ ) and weighed. Production data for each mixture were grouped into forage species, weedy species, and total for further analysis.

Data were analyzed using a split plot analysis of variance, with stubble height as whole plots and species mixtures (introduced or native) as sub-plots.
Analysis showed no significant effect of type of species mixture (introduced or native) on overwinter storage of soil water. Consequently, soil water data for the two species mixtures were combined for further analysis. The relationship between increased soil water content and stubble height was established with linear correlation-regression analysis.

Analysis of forage species, weedy species, and total dry matter production showed that the response to stubble height was significantly different for the two species mixtures. Therefore, further production analyses treated the two types of mixtures independently. The yield response of each mixture was analyzed by linear correlation and regression analysis techniques to establish relationships between production, overwinter stubble height, and increased stored soil water.

\section{Results}

\section{Soil Water Storage}

The depth to which stored water was increased from meltwater of snow catch over the winter of 1976-77 increased with stubble height. Stored soil water accumulated to a depth of 61,94 , and 162 $\mathrm{cm}$ for stubble heights of 15,30 and, $60 \mathrm{~cm}$, respectively. Soil water below these depths did not change. Overwinter increases in stored water content to a depth of $1.8 \mathrm{~m}$ ranged from $1.83 \mathrm{~cm}$ under the $15-\mathrm{cm}$ stubble to $12.67 \mathrm{~cm}$ under the unclipped $60-\mathrm{cm}$ stubble (Table 2).

Table 2. Change in soil water content from October 1976-April 1977 to a depth of $1.8 \mathrm{~m}$ under three heights of grass stubble left over the winter.

\begin{tabular}{cc}
\hline $\begin{array}{c}\text { Overwinter stubble height } \\
\text { stubble height } \\
\text { cm }\end{array}$ & $\begin{array}{c}\text { Stored soil water } \\
\text { soil water } \\
\mathrm{cm}\end{array}$ \\
\hline 60 & $12.67 \mathrm{a}^{1}$ \\
30 & $5.54 \mathrm{~b}$ \\
15 & $1.83 \mathrm{~b}$ \\
\hline
\end{tabular}

'Average values followed by a different letter differ significantly at the $5 \%$ level of probability according to Duncan's multiple range test.

Correlation and regression analysis showed that stored water was highly correlated with height of the grass stubble that remained over the winter (see Fig. 2). Based on the equation shown in Figure 2, which was derived from data collected during the winter of 1976-77, an increase of $0.24 \mathrm{~cm}$ of stored soil water can be expected for each centimeter increase in stubble height (between 15

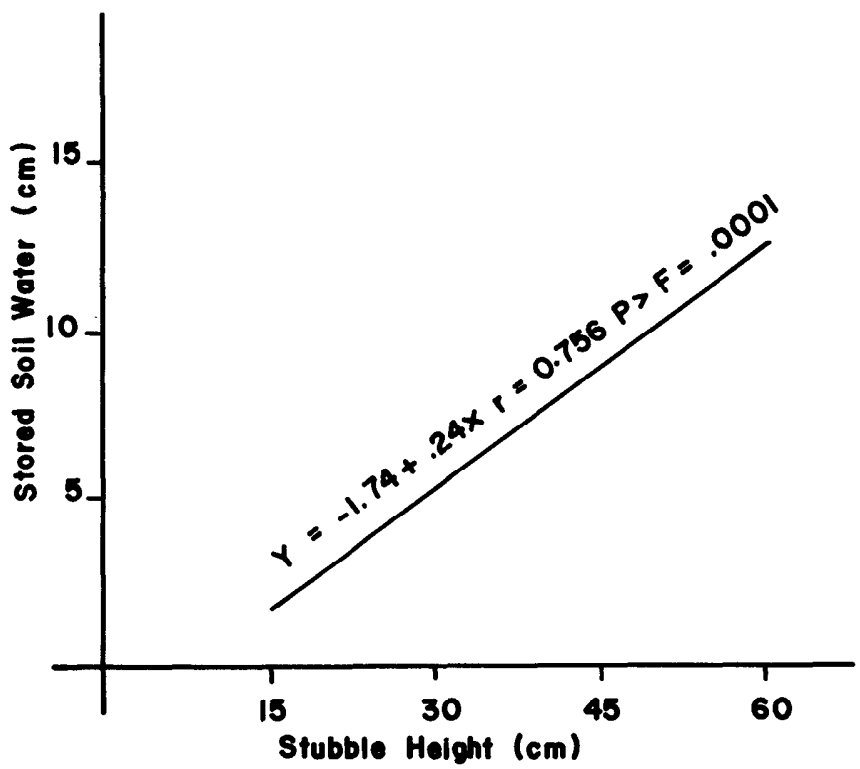

Fig. 2. Correlation coefficient and regression equation for the relationship of stored soil water to height of overwinter grass stubble. 
to $60 \mathrm{~cm}$ of height) that remains over winter. Therefore, each $15 \mathrm{~cm}$ of stubble that could be left over winter would increase stored soil water by $3.6 \mathrm{~cm}$.

\section{Herbage Production 1977}

Analyses conducted for the forage species, weedy species, and total dry matter components of the vegetation show that forage species production increased with increased stubble height $(P=$ .001 ) and that the native mixture produced less forage than the introduced species mixture $(P=.003)$. The production of weedy species was not affected by stubble height, but weed dry matter production was greater in the native $(P=.018)$ than in the introduced mixture. Total dry matter was greater in the $60-\mathrm{cm}$ plots than in the other stubble plots $(P=.003)$, but there was no measurable difference between the native and introduced species mixtures. Table 3 presents species composition of the vegetation harvested in 1977 from the introduced and native mixtures. These data show that more weeds were present in the native mixture than in the introduced mixture. We believe that the difference was related to the difficulty to establishing native species.

Table 3. Total species composition (percentage on weight basis) of dry matter harvested from introduced and native mixtures in 1977.

\begin{tabular}{llll}
\hline \hline Introduced mix & & \multicolumn{2}{c}{ Native mix } \\
\hline Smooth bromegrass & $11 \%$ & Western wheatgrass & $33 \%$ \\
Russian wildrye & 15 & Slender wheatgrass & 36 \\
Alfalfa & 11 & Sideoats grama & $\mathrm{T}$ \\
Pubescent wheatgrass & 55 & Blue grama & 1 \\
\cline { 2 - 2 } & 92 & & 70 \\
Weeds & 8 & Weeds & 30 \\
& 100 & & 100 \\
\hline
\end{tabular}

Herbage production of the introduced mixture ranged from $1,702 \mathrm{~kg} /$ ha where $15-\mathrm{cm}$ stubble remained over winter to 3,706 $\mathrm{kg} / \mathrm{ha}$ where stubble had been unclipped $(60 \mathrm{~cm})$ (Table 4). Weedy species production was greatest where the $15-\mathrm{cm}$ stubble remained over the winter (Table 4).

Table 4. Production of introduced and native mixtures as related to height of the stubble left over the previous winter (1976-77).

\begin{tabular}{clclc}
\hline \hline & \multicolumn{3}{c}{ Herbage production $(\mathrm{kg} / \mathrm{ha})$} \\
\cline { 2 - 5 } $\begin{array}{l}\text { Overwinter } \\
\text { stubble height } \\
\mathrm{cm}\end{array}$ & \multicolumn{2}{c}{ Introduced mix } & \multicolumn{2}{c}{ Native mix } \\
\cline { 2 - 5 } & $\begin{array}{l}\text { Seeded } \\
\text { species }\end{array}$ & Weedy & Seeded & Weedy \\
\hline 60 & $3706 \mathrm{a}^{1}$ & $79 \mathrm{~b}$ & $2208 \mathrm{a}$ & $806 \mathrm{a}$ \\
30 & $1835 \mathrm{~b}$ & $61 \mathrm{~b}$ & $1654 \mathrm{ab}$ & $537 \mathrm{a}$ \\
15 & $1702 \mathrm{~b}$ & $338 \mathrm{a}$ & $1189 \mathrm{~b}$ & $1237 \mathrm{a}$ \\
\hline
\end{tabular}

'Average values in columns followed by a different letter differ significantly at the $5 \%$ level of probability according to Duncan's multiple range test.

Forage species yield in the native mixture peaked at $2,208 \mathrm{~kg} / \mathrm{ha}$ where $60-\mathrm{cm}$ of stubble remained over winter (Table 4). Weedy species in the native stand were not significantly affected by stubble height over the winter (Table 4).

Results of correlation and regression analyses show significant relationships between forage production, overwinter stubble height, and stored soil water for both the introduced and the native mixtures (Fig. 3 and 4). Weedy species production was not related to overwinter stubble height or to increased stored water for either mixture.

Based on the relationship developed from the data collected in this study, a $1-\mathrm{cm}$ increase in stubble height (between $15-60 \mathrm{~cm}$ of stubble) left over the winter would increase forage production by the introduced species $47 \mathrm{~kg} / \mathrm{ha}$ and native species $22 \mathrm{~kg} / \mathrm{ha}$. Forage production would be increased 115 and $62 \mathrm{~kg} / \mathrm{ha}$, respectively, for each $1-\mathrm{cm}$ increase in overwinter stored soil water.

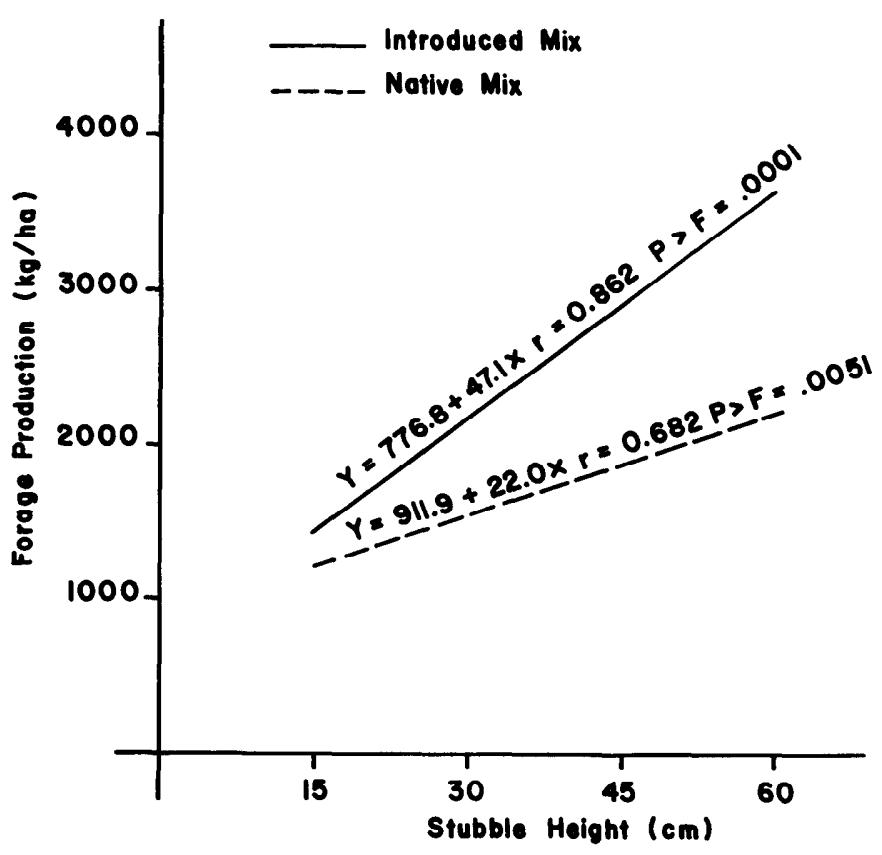

Fig. 3. Correlation coefficients and regression equations for the relationship of forage production to height of grass stubble left over the previous winter for introduced and native mixtures.

\section{Discussion}

Many environmental factors affect the conversion of snowpack into soil water available for use by vegetation. Snowfall variability between winters and the water content of snow are of prime importance. If snowfall or snow water are below normal, little change in stored soil water content can be expected. Also important are the size and location of the contributing area from which snow can be transported. Other important factors such as winter temperatures, humidity, and wind affect the amount of water lost from the snowpack. Soil permeability, soil water storage capacity, antecedent soil water content, topography of the land area, and the rate at which the snowpack melts also affect soil water storage.

The results from this study show the net gains in soil water storage over the winter of 1976-77 on a Parshall fine sandy loam

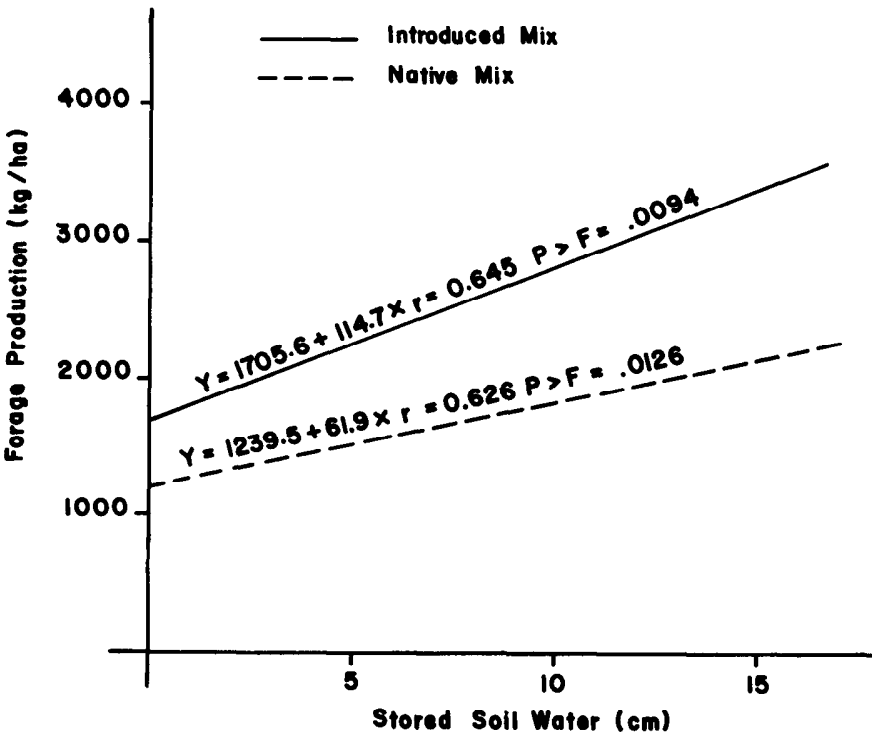

Fig. 4. Correlation coefficients and regression equations for the relationship of forage production to stored soil water for introduced and native mixtures. 
soil. All factors mentioned above and possibly others affected the net change in soil water observed. These can be expected to vary from year to year and with soil type, and this must be considered in use and interpretations of the data presented.

An evaluation of the conditions during the winter of 1976-77 and of site characteristics where this study was conducted showed a situation favorable for maximum conversion of snow catch to stored soil water. The snowfall was near normal; the soil was dry at the start of the snowfall season; the soil had been deeply tilled to increase infiltration; the area was level to minimize runoff; and the windspeed was somewhat less than normal.

The response of the vegetation to increased stored soil water was also accentuated by low precipitation received during the 1977 growing season, thus increasing the dependence of plant growth on stored soil water. Our study illustrated the protection against drought that can be obtained in the Northern Great Plains by increasing soil water stored from snowmelt, suggested by Wight et al. (1975).

Although these results are not directly applicable to rangeland, they were a quantitative estimate of the effect of stubble height on snow catch and subsequent soil water recharge and herbage production. Grass stubble heights can be controlled by grazing management.

Herbage production response of introduced forage species in this study $(115 \mathrm{~kg} /$ ha per $\mathrm{cm}$ of soil water) was comparable to that of Elymus junceus Fisch. (93 kg/ha per cm of soil water) reported by Greb and Black (1971). Smika et al. (1965) measured increases in yields of native mixed prairie forage of about 50 to $100 \mathrm{~kg} /$ ha per $\mathrm{cm}$ additional water after applying 20 to $40 \mathrm{~kg} \mathrm{~N} /$ ha as compared to $62 \mathrm{~kg} / \mathrm{ha}$ per $\mathrm{cm}$ of soil water for native forage species in this study.

The lower response of the native forage species in this study does not necessarily indicate a lower productivity because there were fewer native forage specics established in the native stands. Since weedy species did not respond favorably to increased overwinter stubble height or soil water, stands fully stocked with desirable forage species benefit more from conversion of snow catch to stored soil water than would weedy stands. The significant increase in production of weedy species in the introduced mixture under the 15-cm stubble height (less stored water) seemed to indicate that weeds are strong competitors when soil water becomes limiting.

The significant increase in stored soil water and forage production in response to relatively small increases in the height of grass stubble left over the winter is encouraging. Research on techniques that can put this principle into practice on Northern Great Plains rangeland merits further attention.

\section{Literature Cited}

Black, A.L., and F.H. Siddoway. 1971. Tall wheatgrass barriers for soil erosion control and water conservation. J. Soil Water Conserv. 26:107111.

Greb, B.W., and A.L. Black. 1971. Vegetative barriers and artificial fences for managing snow in the Central and Northern Plains. p. 96-111. In: Proc. Snow and Ice in Relation to Wildlife and Recreation Symposium. Arnold O. Haugen (ed.). Ames, Ia.

Haas, H.J., and W.O. Willis. 1968. Conservation bench terraces in North Dakota. Trans. ASAE 11:396-398, 402.

Haas, H.J., and W.O. Willis. 1971. Water storage and alfalfa production on level benches in the Northern Plains. J. Soil Water Conserv. 26:151-154.

Matthews, G.D. 1940. Snow utilization in prairie agriculture. Pub. No. 696. Canada Dept. of Agr.

Nicholaichuk, W., and D.I. Norum. 1975. Snow management on the Canadian prairies. p. 118-127. In: Proc. Snow Management on the Great Plains Symposium. Research Committee. Great Plains Agr. Coun. Pub. No. 73. Lincoln, Nebr.

Rauzi, Frank. 1968. Pitting and interseeding native shortgrass rangeland. Res. J. 17. Wyo. Agr. Exp. Sta., Univ. of Wyoming, Laramie. 14 p.

Rauzi, Frank, Leland Landers, and Richard Gray. 1973. Level benches for Northern Plains rangelands. Montana Farmer-Stockman 60:22-23.

Smika, D.E., H.J. Haas, and J.F. Power. 1965. Effects of moisture and nitrogen fertilizer on growth and water use by native grass. Agron. J. 57:483-486.

Wight, J. Ross, E.L. Neff, and F.H.Siddoway. 1975. Snow management on eastern Montana rangelands. p. 138-143. In: Proc. Snow Management on the Great Plains Symposium. Research Committee. Great Plains Agr. Coun. Pub. No. 73, Lincoln, Nebr.

Willis, W.O., and H.J. Haas. 1969. Water conservation over winter in the Northern Great Plains. J. Soil Water Conserv. 24:184-186.

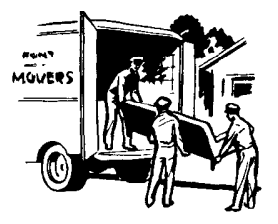

CHANGE OF ADDRESS notices should be sent to the Managing Editor, 2760 West Fifth Ave., Denver, Colo. 80204, no later than the first day of the month of issue. Copies lost due to change of address cannot be replaced unless adequate notice is given. To assure uninterrupted service, provide your local postmaster with a Change of Address Order (POD Form 3575) indicating thereon to guarantee forwarding postage for second-class mail. 